\title{
DOUM- PALM IN ANCIENT EGYPT
}

\author{
Alya Abd El-Ghany Ismail \\ Samar Mohamed Mosleh Mohamed \\ Mofida Hassan Abd- El-Waheed El-Weshahy \\ Faculty of Tourism \& Hotel Management -Suez Canal University
}

\begin{abstract}
:
Doum-palm is the second kind of palms which have been cultivated in ancient Egypt. Doum-palm is not less important than date-palm, but there has been an increasing and wide- spreading of date-palm more than doum-palm.
\end{abstract}

\section{Introduction:}

Palm-Tree is one of the most important and prominent topics and the evidence of that their descriptions prevails graves especially during the New Kingdom Period. The views shows trees in public and palms in particular, where represented the palm is an important element and key in gardens views, which are engraved on the walls of many tombs of private tombs of individuals and nobility and also formed a vital model in the architecture and art as palm style columns prevalent since the Old Kingdom until the end of Ancient Egyptian civilization, it has continued and followed for a long time later. ${ }^{i}$ Plants decorations were spreaded on pots and tools since prehistoric times, which represents the natural lines leaf trees. ${ }^{\text {ii }}$

\section{The Names of Doum-Palm:}

\section{English Name: Doum-palm ${ }^{\text {iii }}$}

iv نخيل الدوم:Arabic Name

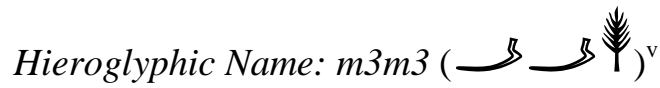

The Doum-palm has been cultivated in Egypt since the immemorial time for different purposes,

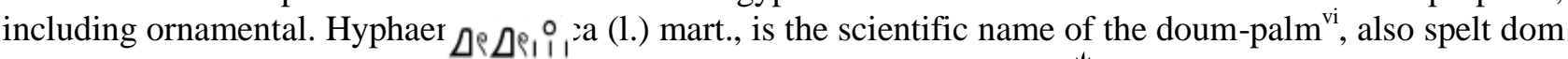
or dum. ${ }^{\text {vii }}$ The ancient Egyptian name of doum-palm is (m3m3__ 3$)^{\text {viii }}$ and its fruits called (kwkw ). ${ }^{\mathrm{x}}$ Doum-palm which has known as "El-Nakheel El-Bahari", live about 100 years. ${ }^{\mathrm{x}}$

\section{Description:}

It is a dioecious fan palm with a repeatedly Y-forked stem up to 20 meters in height; each stem

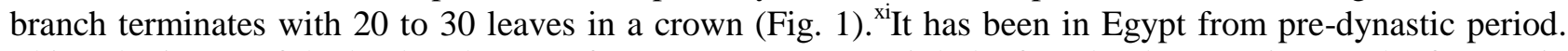
This palm is one of the landmark trees of Upper Egypt, can mainly be found today growing south of Asyut in the Nile Valley. However, its northernmost wild occurrence is in a valley called "Wadi Doum", which located about fifty-six K. M. south of Suez, along the Red Sea. ${ }^{\text {xii }}$ The doum-palm grows up to ten meters tall, and easily distinguished from other palms by the unique forked or multiple trunks. The large seeds germinate readily; they produce long "sinkers" before any top growth is visible. This tree is suitable for warm temperate to tropical climates and is extremely drought tolerant. ${ }^{x i i}$ The doum fruit is the size of an apple, a red-orange color and tastes like gingerbread. It is about seven or eight centimeters long and similarly broad, irregular and bumpy in shape, and its pericarp is a glossy brown in color. ${ }^{\text {xiv }}$

Theophrastus called the tree Koukiophoron, a word evidently derived from Egyptian kuku. He gave a good description of the fruit, and contrasted it with that of the date palm " ... it has a peculiar fruit, very different from that of the date palm in size, form and taste: for in size, it is nearly big enough to fill the hand, but it is round rather than long: the color is yellowish, the flavor sweet and palatable. It does not grow bunched together like the fruit of the palm, but each fruit grows separately: it has a large and very hard stone". Pliny who described the tree as having branches spread out like arms. ${ }^{\mathrm{xV}}$ 
It produces a deep principal root and many lateral roots. The wood inside the palm is a light chocolate-brown with black fiber. Leaves are large, leathery, palmate dissected, with a long leaf stalk of about one meter, on the sides of which are many hooks. Flowers are small and yellow and appear from February until April. One male tree will suffice for a great number of females, even situated at a far distance. $^{\text {xvi }}$ The fruits are bumpy, glossy brown, large brown fruits tasting like gingerbread, about 4 to $6 \mathrm{~cm}$ long, occur high up among the fan-shaped leaves. ${ }^{\text {xvii }}$ The fruit is eaten raw after being soaked in water or is made into a syrupy decoction. ${ }^{\text {xiiii }}$ The sweet fruits of sidder were again consumed raw or fermented for winemaking. ${ }^{\text {xix }}$ This palm produces fruit without artificial pollination. Seeds have been collected in the wild in Upper Egypt or0 buy them on the market in almost any large town or city. ${ }^{\mathrm{xx}}$

Male flower of doum-palm has three lobed, imbricate. Petals ovate broadly, concave, connate into a short stalk at the base and have six Stamens. Female flower is shortly larger than the male. Sepals are ovate orbicular, and imbricate. Petals are slightly smaller than the sepals, broadly ovate, obtuse and imbricate. Flowers immersed in the branch-lets, the male in pairs, the female solitary. Species about 9, dispersed through tropical Africa, Arabia, and the Mascarene Islands. ${ }^{\text {xi }}$

The outer pulp is often used for making the doum drink so that the cleaned seeds without pulp can be bought cheaply from spice and herb shops. Seeds should be planted out when they are about one year old. Sandy soil is the most suitable, but the plants will also grow in heavy soil. If seeds are sown directly into the ground, they should be regularly watered for a few months, but very few will germinate. Growth of this palm is slow: it starts to produce fruits after 5 to 6 years when the stem is about 1.5 meter high. ${ }^{\text {xii }}$

It is said that both Strabo and Pliny description of the doum-palm under the name of Theban palm was wrong, while Strabo thought that the Theban dates is the best dates, while Pliny thought that it's the worst dates grow in Egypt, and is likely to be both means of different fruit type and not the fruits of doumpalm. ${ }^{\text {xiii }}$ The only palm indigenous to the Nile Valley was the doum-palm, characterized by the multiple forks in its trunk. The fan-shaped leaves offered raw material for weaving into mats, bags, and baskets, and its fruit is edible. ${ }^{\text {xiv }}$

\section{Cultivation of Doum-Palm from Ancient Egypt and until now:}

The doum-palm has been planted from immemorial time. Ancient Egyptians know it as an important plant divided into two divisions depending on the branches. ${ }^{\mathrm{xxv}}$ It is an African palm in the origin, it has been cultivated in Egypt from the oldest periods and it has been widespread in Upper Egypt, Nubia and Sudan. ${ }^{\text {xxvi }}$ It has been grown spontaneously in Egypt at least from Neolithic times onwards. ${ }^{\text {xxvii }}$ Doum-Palm (Hyphaene thebaica) is also common. Their cuts as well as the fruits of handal (Citrullus colocynthis) are exported with Acacia fruits which are used for tanning. Acacia also yields a valuable wood durable for coating the wells. ${ }^{\text {xxiii }}$ Kurkur Oasis is the part of Wadi Kurkur best covered by dense growth of plants with groves of doum. Two of these wells are permanently open, each actually being a small shallow pool surrounded by reed. Within the area of Kurkur Oasis the water-table is high. ${ }^{\text {xix }}$ In the vicinity of one of the wells is a patch of Imperata cylindrical, a halfa grass similar in appearance to D. bipinnata, which forms a carpet in the area ranging from complete ground cover in the center to sparse cover on the periphery. This green carpet is studded by Hyphaene thebaica and Phoenix dactylifera palms: the former are more numerous. In the central part of the oasis a single bush of Tamarix nilotica was present in 1965 near one of the wells. ${ }^{\text {xx }}$

The Doum-palm is considered a decorated palm which has been cultivated in gardens from the past to nowadays for its beautiful scene. Dom-palm grows slowly, its nut cover is a tough cover and the leaflets were used firstly in holding the roofs and the signs of ships. ${ }^{\text {xxi }}$ Dom-palm ' wood distinguish by its unable to be eaten by insects in addition to that water increases its strong unlike the metal pipes have been oxidized and corroded along the time. It has been found a doum-palm pipe bear in the El-Moharaka area in the outside oases from the Romanic period and it is presented now in the Egyptian agriculture section in the Egyptian museum. It is consisted of two long parts tied with each other by a wood cut. These have been used until now in the oases especially in the deep wells, it has been established by a straight way in the water' nozzles and water flows from it. ${ }^{\text {xxii }}$

It was common in Upper Egypt in the provinces of Qena and Aswan and rarely found in other places. The fruits grow during February and March months, and sometimes in April. There is a large impact on doum-palm influenced by the environment in which it grows. If dry atmosphere transplant like El-Kharga Oasis, its fruits were small similar to other fruits, but if it planted in a wet atmosphere, it will be very sweet. 
It used in the same uses of date palm, but the advantage of it that its timber is better, stronger, heavier and well-tolerated than the date-palm timber. ${ }^{\text {xxxiii }}$

Today, the Doum-palm is a little, low-branching and much less abundant than the date palm. ${ }^{\text {xxiv }}$ These palms grow individually or in small scattered clumps along the desert margin: these are seldom found close to water. ${ }^{\mathrm{xxx}}$ It wide spreads in the plains from Senegal to Egypt. It restricted mainly to the southern part of Egypt. It was first described from Thebes, hence the epithet thebaica. The doum-palm tolerates a wide range of soil conditions. It grows in the southern part of the Nile valley on salty soil and in small oases in the western desert on sandy soils. The tree can also grow in beds of valley or on its fill and deposits. It tolerates high temperature and even fire. ${ }^{\text {xxxvi }}$

The hard seeds have been used in small decorative items, which are sometimes called "vegetable ivory" and have been used commercially for making buttons, ${ }^{\text {xxxvii }}$ but today it has no commercial value. ${ }^{\text {xxxviii }}$ Tackholm and Drar note that a factory was once established for this purpose in Suez. ${ }^{\text {xxix }}$ And the much visited group of stately branching palms situated at the mouth of the doum Valley, approximately 35 miles south of Suez, along the Red Sea. ${ }^{x 1}$ The trunk of the doum-palm which are considerably harder than that of the date palm, furnishes roof timbers for Nubian houses. ${ }^{\text {xli }}$ The compact timber of the doum-palm was useful building material so that leaves, stalks and fibers were used in matting, basketwork and funerary garlands etc. The fruit kernels served to make small objects of daily life. .lii $^{\text {lii }}$

Doum palm is distributed in Arabia, Western Asia, and all over tropical and sub-tropical Africa. ${ }^{\text {xlii }}$ It was wide-spread in the southern part of Egypt, though now it is much rarer and only found upstream of Qena. ${ }^{\text {xliv }}$ Nowadays, the tree is very common in Upper Egypt especially in Qena and Aswan, and in el Kharaga and Dakhla Oasis. ${ }^{\mathrm{xlv}}$ It have been increased in the south areas Egypt like el-Dakhakhen area, Elmakes El-bahary and El-kebly and Dosh, El-Orman garden, Zoo garden, El-Azbakeya garden, Mohammed Ali garden at El-Rawda island and agriculture faculty at el-Giza, ${ }^{\text {xlvi }}$ but is rarely seen elsewhere in Egypt. ${ }^{\text {xlvii }}$

Dom-palm nut is in the size and shape of a small capsicum and the appearance of varnished wood and grow in bunches. ${ }^{\text {xlviii }}$ Doum-palm was presented in many tombs from the Eighteenth Dynasty Period during the New Kingdom in Thebes. Theophrastus mentioned that doum-palm is an Egyptian palm distinguished by its variety forks, which is unusual in the palmate. There are many examples for doum fruits which have been found in tombs since the New Kingdom (Fig. 2). ${ }^{\text {xlix }}$

\section{Benefits and Uses of Doum-Palm in Ancient Egypt:}

\section{In furniture and daily life:}

Many travelers authors like Strabo pointed that every part of the Doum-palm in a certain industry, the fruit kernels used to make earrings, twigs used to make slippers and sandals, while palm wood used for making the foot of cartridges and branches used to make longitudinal menus that adorned the temples pylons. The timber of the Doum-palm is strong, compact, and heavy and has been used for many purposes in furniture, agriculture, and building. Its leaves have been widely used for basketry, ropes, and fibrous items

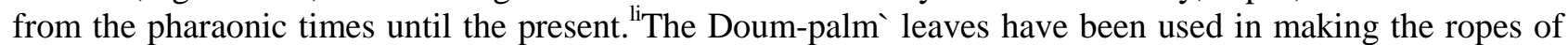
the hamlet of king Sahure during the fifth dynasty, era of new kingdom, these ropes reached to about 300 arm*. ${ }^{\text {lii }}$ As for the Doum-palm` wood has been used in making stocks and it is off-brown color, its leaflets have been used in making ropes, leaves have been used in making pickers and gabions. Doum fruits have been used in eating or as a laxative drink by putting Doum in a vase filled with water after removing its covers, its nuts have been used in making buttons, there is a factory in Suez to making buttons from dom nuts and rosaries and children` joys. ${ }^{\text {liii }}$

Vogt describes the uses of this palm in African countries where its different parts are intensively used, for example, in Kenya; the powdered fruits are used to make a mild alcoholic drink, while in other countries a wine is made from the palm sap. ${ }^{\text {liv }}$ In the tomb of king Tut-Ankh-Amun, there were several baskets containing well preserved doum-palm fruits in the size of tennis balls but more or less cubic in shape with rounded corners such as a basket displayed now at the Agricultural Museum under the number 174 (Fig. $3)^{\text {lv }}$ When the fresh smooth covering can be peeled off to expose the thin, a very fibrous layer surrounded the large kernel. This layer is sweet and taste of caramel if gnawed with considerable patience. ${ }^{\text {lvi }}$ Several 
species of doum-palm with forked trunks have a wide distribution in the drier parts of tropical Africa south of the Sahara, but it is now considered that $\mathrm{H}$. thebaica in the strict sense is limited to Sudan and Egypt. ${ }^{\text {lvii }}$

The primary use of the doum-palm was not as a provider of food and the evidence of that the firstly fragments of doum fibres were identified in mats and its wood and stone were useful building materials and served to make small objects of daily use. According to Beadnell and Llewellyn " the spongy internal portions of the nut forms an important article of food in some parts of the Sahara and, when mixed with an infusion of dates, constitutes a cooling drink much valued in febrile disturbances...". lviii Theophrastus stated that in Nubia and Upper Egypt its fruit was used to make a variety of bread, and both he and Pliny noted that curtain rings were made out of its stone. ${ }^{\text {lix }}$

The fruit is eaten either raw, or after being soaked in water, or made into a fresh drink or syrup, though the tree`s primary use was not as a food, but as a source of material for building and objects of daily use. All parts of the palm have been and still are used in Egypt. The fruit`s hard, white nut is used to make buttons, rings and beads, the rind of the doum nut is used to make molasses, the leaves are used to bind parcels, used as a writing paper and are woven into mats. There is a pre-dynastic example has been found and is preserved at the Cairo University herbarium. The wood was used in shipbuilding. ${ }^{1 \mathrm{x}}$ The outer fibrous layer was soaked and pulped to be baked in bread. doum-palm kernels were burned to make the charcoal nuggets used for incense burning. ${ }^{\text {lxi }}$

\section{The Medical Importance of Doum-Palm:}

Medically, the fruits and roots are used in traditional medicine. ${ }^{\text {xii }}$ Theophrastus said that; bread made from doum fruit would cure stomach ailments and the nuts were ground to dress wounds, Bedouins uses Dom in these utilizes until now, Deoskores also mentioned to the medical uses of Dom. ${ }^{\text {Ixiii It }}$ was used in treating the burns of bladder and the blooded boll and treating the broke. ${ }^{\text {lxiv }}$ Medically, Theophrastus wrote that bread made from doum fruit would cure stomach ailments and the nuts were ground to dress wounds. He also mentioned to the medical importance of doum- palm bread as a treatment for ailments. ${ }^{1 \mathrm{lv}}$ Dom has been mentioned in Ebres Papyrus including to medical prescriptions. ${ }^{\mathrm{lxv}}$ Montet stated that the fruit was commonly used in Ancient Egyptian medicine, but the only mention of anything remotely like it in the medical papyri is a prescription in the Rameses V Papyrus, recommending "mAA", a fruit, that Dawson thought could be a variant of mama (mAmA), or a coping mistake. . $x v i i$

\section{Examples of Founded Doum Fruits in Tombs:}

The ancient Egyptians buried the plentiful fruit in tombs from prehistoric times onward and Ramesses III offered large measures of them to the God Amun-Re at Thebes. The tree appears in many tomb paintings as in tombs of Rekhmire (TT100) and Sennedjem (TT1) at Thebes. Also, a very rare depiction of the fruit was found on the walls of Sennefer`s tomb (TT96) at Thebes. Many complete fruits and fruit fragments were found in the tombs and remains of the fruit found in Tut-Ankh-Amun`s tomb are on display in the Agricultural Museum. lxviii $^{\text {. }}$

Petrie found Doum fruits in a tomb at Kahun from XII dynasty. He also found fruits of doum-palm in a tomb at Hawara from the Greco-Roman Period. Baskets, ribbing of seat of a chair and sandals, all from XVIII dynasty, kept in the Agricultural Museum, Cairo, were identified as split petioles or leaf lobes of Doum-palm. Leaves of doum-palm were found from XVIII dynasty. And also leaves of Doum-palm were found in the tombs at Drac Abu el Naga, from XX-XXVI dynasties. There are several doum fruits, which Moller found in Thebes, from the reign of Tuthmosis IV during the New Kingdom, and now presented in the Berlin Museum. There are examples of Dom fruits were found in the tomb of king Tut-Ankh-Amun, now kept in the Agricultural Museum, Cairo. Maspero also found several doum fruits in the tomb of Sennedjem at Thebes, XVIII dynasty during the New Kingdom. ${ }^{\text {lxix }}$

Also many objects were found and displayed now at the Agricultural Museum, Cairo, probably from the Roman Period baskets, bottom of a bag, a basket lid and seat of a chair which were identified as doum. ${ }^{\text {xx }}$ In addition to that there is a sample of palm-fibre sling from the Middle Kingdom found at pyramid-builders town of Kahun displayed now at Manchester Museum under number (Acc. No. 102), most likely used as an aid in climbing trees (Fig. 4). ${ }^{\text {lxi }}$

\section{Doum-Palm in the Ancient Papyri:}


The Doum-palm and its fruits were mentioned in the New kingdom papyri; where Amenemope speaks to the scribe Pentwere. This letter is brought to you to the following effect "PA mAmA aA n $60 \mathrm{mH}$ pA nty qwqw im.f wn xAnyny Hnw qwqw iw mw $m$ Hnw "... thou great Doum palm of 60 cubits, on which there are nuts, there are kernels in the nuts and water in the kernels". In Harris I papyrus, it is mentioned that Ramesses III, offered to Amun-Re at Thebes "Hw qwqw m ipt 449,500 "Dom-palm fruits; in measures (ipt) $449,500 "$. And also we find that the demotic word qwqw was frequently mentioned on an Ostraca which were found in Thebes. ${ }^{\text {lxxii }}$

Doum-palm fruits were also used in making cakes and there is referring to that in the writings on the walls of the cemetery of Rekhmire who said "200 Cakes of doum were provided for the gods. It is mentioned in ancient texts that Ramses III who was one of the kings of the Nineteenth Dynasty gave the temples of Egypt 514 gardens planted with a variety of trees including doum-palm. lxxiii

There is a list of sacred trees for Dendera area in its great temple. it has mentioned to the doum-palm stated on Dorpat' panel which carrying in its upper part a sarcophagus with a Goddess takes the form of river' mare (Taort, the great special for doum-palms) and there are three doum-palms behind the sarcophagus, and in the lower part, there are a man and a woman in a worshipping state and their prayers occupies the rest of the stone in vertical lines starting with (reverence Taort special for doum-palms). It has also been found a plate made out of limestone in Deir el-Medina area. The plate represented the special paper of doum-Palm next to the cabin and hieroglyphics (Taort special for Doum-palms). ${ }^{\text {lxiv }}$

\section{Historical Background of palms and its views:}

Tackholm and Drar went so far as to state that there is no period of Egyptian history from which finds of doum have not been reported. Ancient Egyptians represented palms in many descriptions, on ostraca, on jewels, and in the many paintings of the gardens that the deceased wished to visit after his death, to enjoy the cool shade of its leaves and the tasty fruits that he liked. ${ }^{\mathrm{lxxv}}$

Ancient Egyptians considered Doum-palm as one of the trees that grow in the gardens of the other life, which the deceased wished to visit after their death to enjoy the tasty fruit and cool shade. ${ }^{\text {lxxi }}$

\section{Examples of Scenes of Doum-Palm in Ancient Egypt:}

It has been mentioned in the previous chapter to many scenes which contains Doum-palms with Date-palms in the same time and one scene which contain the both kinds of palm and also the third one, Argun-palm, these scenes such as:

\section{A Scene of Ineni` Garden:}

The scene contains 120 Doum-palms as it has been mentioned before. ${ }^{\text {lxvii }}$ There is a mention of the list contained Date-palm and Doum-palm on one of the walls of Ineni tomb including the most visible trees in his garden. Doum-palms are showed for the first time higher three times than the other palm-trees in the view which is formed in two rows part complement the top of the image of the garden and features the ramifications of its subsidiaries, as well as the form of fronds, which takes the form of the fan more than a Date-palm, circular doum nuts (Fig. 5). ${ }^{\text {lxxiii }}$

\section{A Scene of Sen-Nefer Garden:}

This Scene represented the garden which (Sen-Nefer) hopes to be for him in the otherworld, views about 22dom-palm distributors on the entire scene divided among the rows of trees in the scene, a row on the right side after the wall that surrounds the park, another row after the entrance which follows the wall. ${ }^{\text {lxxix }}$ On the left, there is a horizontal row of palms, which includes doum-palms (Fig. 6). ${ }^{\text {lxx }}$

\section{A Scene of Ka-En-Amun`Garden:}

This Scene depicts a rectangular water pond surrounded by a wall which surrounded by a garden of vineyard supported and mounted on columns with open papyrus capitals with a trelliswork and a range of fruit trees including eight Doum-palms which are represented by branched trunks and groups of Doum fruits on each side of the palms (Fig. 7). ${ }^{\text {lxxxi }}$ 


\section{A Scene of House`garden of "Ka-En-Amun" on a Panel in the British museum:}

A Panel in the British museum under the number (37983), represents a house' garden of (Ka-EnAmun), who was working during the reign of King Thutmose III or Thutmose IV, era of eighteenth dynasty during the New Kingdom period. The panel represents a rectangular pool located in the mid-scene filled by a group of fish, ducks and geese, as well as papyrus plants. There is also a group of papyrus plants and poppies surrounds the pool and all of that surrounded with a group of trees and shrubs includes a number of sycamore trees and date-palms, doum-palms and argun-palms (Fig. 8). There is small representation in the right side of the view a lady who may be ordering and putting the fruits of Sycamore, Dates, Doum and Argun on the offering table and arrange the pots on that table to be presented to the gods. ${ }^{\text {lxxii }}$

\section{A Scene of Rekhmire` Garden:}

This scene represented a group of trees surrounding a pool or water square, these trees are included doum-palms which represented with a high attitude with big doum fruits (Fig. 9). ${ }^{\text {lxxiii }}$

\section{A Scene of palm-trees in Sennedjem`Tomb:}

A scene of date-palms and doum-palms located at the east wall of Sennedjem`s vaulted crypt which is decorated with a vignette that illustrates spell number 110 in the book of the deed in his tomb no. TT1 at Thebes. ${ }^{\text {Ixxiv }}$ The view represents the most important palms and trees in paradise fields (Iaru) which represents paradise that deceased wishes to be for him after his death (Fig. 10). ${ }^{\text {lxxv }}$

The scene represents a row of trees and palms where includes four doum-palms. Doum-palm has represented so that its trunk is divided into two parts, each part has two branches carry about 4or5groups of the fruits of Doum. ${ }^{\text {lxxxvi }}$

\section{A Scene of Sobek Hotep garden:}

This scene of six rows, five were with the same height includes Doum-palm. These palms are represented while the fruits divided in groups in each side of the palms (Fig. 11). ${ }^{\text {lxxvii }}$

\section{A Scene of Nakhet and His Wife in front of God Osiris and Goddess Maat:}

In In the right of this scene, there is a shrine probably represented the cemetery of the deceased and its false door in front of a sycamore tree, followed by a doum-palm with five fronds with four groups of doum fruits, two on each side were represented in a smallest way about the deceased and his wife (Fig. 12). lxxxiii

\section{A Scene of palms in punt mission`yields on the Punt portico at Hatshepsut Temple:}

This scene is represented on the south east wall of the temple of Queen Hatshepsut during Eighteenth Dynasty, New Kingdom Period. The scene shows punt mission which has been sent by the queen during her reign to bring some yields from punt land. ${ }^{\text {lxxix }}$ The first and second register shows a group of workers carrying yields that have been imported from Punt land (Fig. 13, 14). ${ }^{\mathrm{xc}}$

This scene shows punt mission which shows three doum-palms by showing of the palms with old trunks and merge with new trunks from above. ${ }^{\text {xci }}$ There is a doum-palm representation with lively way acquired the art of engraving during the period of Queen Hatshepsut and king Tuthmosis III, the palm was represented fetched from Punt land, its crowns have two even three branches. ${ }^{\text {xcii }}$ At the tomb of "wsr-h3t" No. 51 at Thebes, there is representation of doum-palm, which features with its distinctive branches taken the form of a fan. xciii

\section{Ken-Amun represents Doum-palm`Branches as Offerings:}

This scene represented on the west wall, south side of the outer hall of tomb of ken- Amun. The set piece in goldsmith`s work, with a central device of monkeys in the branches of Dom-palms which is being presented by Ken- Amun to the King Tuthmoses VI, but his figure has been destroyed and forbidden. All the doum-palms are represented by the same shape with many branches and groups of fruits are descended from both sides of every palm (Fig. 15).xciv 


\section{Shuna' Scene in the Tomb of Sennefer:}

This scene is represented at the northern end of the transverse hall of the tomb of Sennefer is heavily damaged. The portion remaining shows a part of the shuna (open air grain storage yard) or granary of the Temple of Amun (Fig. 16). The stylized heaps of grain are divided by raised pathways or balks, and a small kiosk and several dom-palms are scattered about the main enclosure. Almost all of the remainder of the structure is now lost, save a few trees in an outer courtyard (upper left). ${ }^{\text {xcv }}$

\section{A Scene of Negroes`Fleeing from King's Soldiers in Kush:}

This scene is represented on one of the walls of Beit El-Waly Temple, built by King Ramses II during his rule in the 19th dynasty, the New Kingdom Period. This scene shows Negroes who are fleeing from the king's soldiers in Kush. A scene of the Battle of Kush and the victory of king of them where they show a racing pace and some of them look back in fear and some clutching sword looks like a cleaver or large knife, all naked representatives only with a short kilt above the knees made out of animals` skins to the presence of some increases (Fig. 17). ${ }^{\text {xcvi }}$

Soldiers were represented with override headed cap covers only the rear portion of their head may represent helmet in this time. In front of them, there are two doum-palms but the landscape was broken only show from the upper branches divided into three branches and three groups of fruits. After that Palm, there is someone hiding behind a doum-palm tree with four branches, but there are no remains of them in the view except two full-size and only two remnants of their trunks hanging from one of the branches visible rivers range of fruits. ${ }^{\text {xvii }}$

The form of palm leaves characteristic magnitude which has mostly showed three papers in each branch. After those palm, there are two men hold third man from his arms who injured in the battle, it is seemed that his wife or one of his acquaintances stand in front of them wearing the mantle up to the bottom of her knees with short hair. In front of and behind her there are two naked small persons may have been the children of the injured or two frightened children. ${ }^{\text {xcviii }}$

In the top side behind the woman there is a naked man except only helmet above his head and portrayed as battling another one in front of him, but he depicts, in front of a doum-Palm with two branches and huge leaves and one group of fruits in its right branch. By looking above the Palm, there is a monkey seems to be in a fear state and paper by the palm during the battle. After the palm from the left side, there is a Lady who represented by short hair and wearing a long cloak sitting squatting, it is seemed that she cook a meal in a pot in front of her which louder than a conferred something may be probably a stove. ${ }^{\text {xix }}$

\section{The Granary of Amun, tomb of Khnummose:}

This is a scene of the granary of Amun in the Tomb of Khnummose, one of the employees during the New Kingdom, Eighteenth Dynasty, reign of King Amenhotep III. All the walls of the granary are white. The main entrance is through a yellow door on the left, leading to three main areas; those in front and to the right are grain stores, containing piles of grain, the smaller store one pile, the larger two, together with grain around the bottom of the pile. There is a sycamore tree in each room. The section on the left consists of three rooms which might be a temple; the first room has a blue and yellow Hathor` head either side of the entrance door, at the back of the room there are four or more jars on yellow stands, above which are flowers (Fig. 18).c

The central passage leads through another white door to four grain stores, two to the left and two to the right, each store with a heap of grain and sycamore tree. A gateway with no door indicated connects to the stairs to the roof. To the left there is a large room full of grain. To the right there are two rooms, each with a heap of grain. The final section shows four rooms containing heaps of grain. That at the bottom and that to the left of the central axis also contain large dom- palms, with green foliage and brownish- red fruit. On the roof which we reached by the stairway, there is Avery small uncaptioned figure of a king standing before a table piled with food; its base are round white loaves, above that a red leg of meat and some red ribs, and on the top some white shapes covered with blue streaks. ${ }^{\mathrm{ci}}$

The table is white and is of the type typically used for bearing burnt offering, flames issue from the top of the food. The king holds in his left hand a hawk-headed censer, and throws pellets of incense into it 
with his right hand. To the right of the table is the outline of a round- topped stela, this has suffered some damage. .ii $^{\text {cigh }}$

\section{A Scene of Doum-palm in the Tomb of Huy:}

There is also a similar scene of a doum-palm on one of the walls of huy tomb No.40 at Thebes. Hwy was working as a Viceroy in Kush in the reign of King Tut-Ankh-Amun. The scene shows a doum-palm made out of gold and monkeys climbed it, while Negroes kneeling begging under the palm (Fig. 19). ${ }^{\text {cii }}$

No actual specimens of the kind of goldsmith`s work here depicted have come to light. To the left of the tribute, at the bottom, Huy is shown kneeling in adoration. This figure is re-inserted over a previous erasure. ${ }^{\text {civ }}$

\section{A Doum-palm`Scene in Mery Re II tomb:}

There is a scene on one of the walls of Mery-Ra II tomb, who was a worker during the era of King Amenhotep IV (Akhenaten), Eighteenth Dynasty, New Kingdom, depicts Mery-Ra II provides a doum-palm for the couple rulers in Tel El-Amarna within the south tribute, shows doum-palm made out of an expensive material (Fig. 20). ${ }^{\mathrm{cv}}$

\section{A Scene of Amun-Nakhet Kneeling beside a Doum-palm:}

In addition to the scenes of a man kneeling beside or under the Date-palm, it has also found similar scenes but with doum-palm not Date-palm that like this scene. The scene is described in the tomb of AmenNakht (no. 218) at Deir el Medina, reign of Ramesses II. ${ }^{\text {cvi }}$ The scene represents Amen-Nakht Kneeling, he worships beneath a doum palm with bunch of fruit on the edge of a water beach and is most likely a sacred pond either put prostration is to the knees on the ground in the alignment of each other and note that the arm is rested entirely on the ground while head resting on the ground and touching the mouth and nose of the deceased water table associated with the view and the view here can be interpreted from more than one point of view as it is a situation which should of worship and respect and submission by the worshiper can also consider that the deceased unquenchable from security water under conditions Doum-Palm (Fig. 21). ${ }^{\text {cvii }}$ It confirms the shadows was the rest of her leg like a shadow in the water fee and benefited from the fruit and branches in both scenes. ${ }^{\text {cviii }}$

Accompanying this scene, four short lines of text read: "A spell for drinking water beside a dom palm beside the feet of the god Min: praise to thee, who come forth from thy shadow, thou sole god who grows from the soil of the earth, and at whose root water is put! Moisten the heart of the Osiris Amennakht" ${ }^{\text {cix }}$

\section{Scenes of Monkeys Climbing Doum-Palm:}

Doum-palm has been associated with ancient god of the Egyptian Thoth, the god of science and knowledge, who was representing in the Apis bull body or baboon, that baboons have feed on the fruits of doum and live in the summit of the palm-trees; so doum-palm was famous as a particular tree for god Thoth. There is a representation of the god Thoth in the shape of baboon on the doum-palm on Ostraca found in Deir El-Medina currently displayed in the Egyptian Museum at El-Tahrir street and the Agricultural Museum at El-Dokki in Cairo and other museums. ${ }^{\mathrm{cx}}$

Baboons were the symbol of wisdom and their affinity for this tree lent the tree the same meaning. The tree is sacred to Thoth god of wisdom who is often identified as a baboon. ${ }^{\text {cxi }}$ It is clear that there were many scenes of monkeys on or beside doum palm that for the importance of monkeys in the collecting of doum fruits process during the Old and Middle Kingdom. In many cases, there is a representation of two baboons collecting special fruits of dates or Dom such as a representative on one of the tombs of the Eighteenth Dynasty currently displayed at Berlin Museum, as well as the representative of the bowl or the bowl (bowl pottery) from the town of Sunset in the Eighteenth or Nineteenth Dynasty. ${ }^{\text {cxii }}$

\section{Examples of These Scenes:-}

** A scene of a monkey with its young on the shoulders caring water for a garden. This scene is drawing on an ostraca which dates back to the eighteenth dynasty period, era of new kingdom, Brussels. In 
front of monkey and its young, there is a doum-palm known by its variety branches and groups of fruits are on both sides of it. After the doum-palm, a sycamore tree is standing by its distinguished shape and a datepalm with many fronds but only one group of fruits and beside it, there is another sycamore tree resemble to the first one (Fig. 22). ${ }^{\text {cxiii }}$

** These baboons were native to the south, such as doum-palm, eat up the leaves and fruits of it, and this has been confirmed by many cut stones made of limestone and such scenes which belong to Dier ElMadina area as well as a representation in the semi-anthropomorphic on a column-shaped paint from Ivory with the shape of doum-palm topped by baboons (Fig. 23). ${ }^{\text {civ }}$

** There is a limestone form of doum-Palm and a baboon climbs the trunk from the right side of it, and the length of this model is about $31 \mathrm{~cm}$ and dates back to the Twelfth Dynasty, Middle Kingdom period. It was found in Abydos and a restoration of its lower part had been as it is seen. Both of the Palm and Monkey were represented in the abstract without any features; there is no distinction of monkey only his face and hands that hold the trunk of The Palm, as well as Palm trunk was represented in the narrowing of the cylindrical shape is slightly above the bottom without any other features (Fig. 24). ${ }^{\text {cxv }}$

**There are various scenes of baboons climbing Palm-Trees in the new kingdom period, especially doum-palm. Many cut stones have been found in the Deir el-Medina area, one of these cut-stones represents two baboons are ready to climb doum-Palm. On the Top, there is a third monkey has already preceded by climbing, walking on the branches while looking back. the artist imaged monkeys accurately indicating grace with tail long and distinctive face, it has also been giving the green color as well as the branches of the palm, and the fruit takes the orange color and trunk such as orange and green with transverse lines with pinpoint accuracy in showing leg and branches and leaves as well as fruits hanging from the Palm in abundance (Fig. 25). ${ }^{\mathrm{cxvi}}$

**There is a scene of a baboon climbing a Doum-palm on one of the crumbs while looking back and is belted by a rope holding by a man standing on the other side of the palm-tree, in which the artist focused to portray the fruits in abundance, as well as three crows eats fruits. This scene is assured that the monkeys were used in the gathering fruits in addition to climb palms for fun and play (Fig. 26). ${ }^{\text {cxvii }}$

**This is a scene of the garden of Puyemere but the scene is too destroyed. Puyemre was working during the new kingdom period. From the remains of the scene, there are three rows of sycamore trees from the right and upper and lower sides. Under the upper and lower rows, there are a row of date-palms in both sides. There is a small basin in the center of the view full by ducks and lotus flowers (Fig. 27). ${ }^{\text {cxviii }}$

**A remain of doum-palm which is climbed by a baboon. The artist represented the palm by a very perfect way showing its trunk and groups of doum fruits on each side (Fig. 28). cxix $^{\text {. }}$

**Three Birds stands on a doum-palm and a baboon climbs it. The birds are represented while standing on the palm ' branches and eating from its fruits which are represented by a big and rich view. The monkey climbs the palm and looks back and a man in the opposite side holds the baboon by a rope that sure the monkey climbs the palm to collect the doum fruits not to just play. The man wears a long cloak and has a shaven-headed (Fig. 29). ${ }^{\text {cxx }}$

**A baboon descends down a date-palm while holding a group of date fruits. However the damage of the figure but it seems that there is another baboon still above the palm (Fig. 30).

**A baboon which is belted by a rope holds by a man. The baboon descends from the Doum-palm by a man who loosens the rope which the baboon belted by (Fig. 31). ${ }^{\text {cxi }}$

**A baboon climbs a Doum-palm but the figure is very damaged showing from it the branches and big Doum fruits and the monkey climbs it while holds by a rope around his chest. There is also a representation of a falcon stands above the palm (Fig. 32). ${ }^{\text {cxii }}$

**A remain of scene of monkey head and his hands while climbing a Doum-palm but the scene is badly painted and damaged (Fig. 33).

**A remain of a scene of a monkey and a bird stands above Doum-palm branches (Fig. 34). ${ }^{\text {cxxiii }}$ 
**A Doum-palm and a baboon climbing it. There is only the trunk of the palm and one frond and one group of Doum fruits to see. In addition to that the baboon` legs and its tail are appeared and a part of a rope which the monkey belted by (Fig. 35).

**A baboon descends a Doum-palm holds a group of Doum fruits in his left hand and holds the palm by his right hand and belted by a rope around his chest (Fig. 36). ${ }^{\text {cxiv }}$

** This scene is similar to the previous scene but there is only a baboon `leg remains and half of another monkey and part of palm` trunk (Fig. 37).

**A baboon sits on a palm` trunk and belted by a rope around his chest and his head and his hands are erased and there is only this branch which is still appeared from the entire palm (Fig. 38). ${ }^{\text {cxxv }}$

${ }^{\mathrm{i}}$ Zahran, M. A., Willis, A. J., The Vegetation of Egypt, Plant and Vegetation, vol. 2, 2nd edition, New York, 2009 , p. 372.

زينب عبدالتو اب رياض خميس، (2010) تطور الأو انى الحجرية فى مصر منذ عصور ما قبل التاريخ حتى نهاية عصر الدولة الوسطى، رسالة دكتور اة

غير منشورة، كلية الآثار ، جامعة القاهرة.

iii Boulos, L., (1983) Medical Plants of North Africa, Cairo, p. 138.

${ }^{\text {iv }}$ Boulos, L., ibid, p. 138.

${ }^{v}$ WB, Vol. II, P. 29; Faulkner, R. O., (2009) A Concise of Dictionary of Middle Egyptian, Oxford, p. 103.

${ }^{6}$ Springuel, I., The Desert Garden, a practical guide, Cairo\& New York, p. 111

${ }^{7}$ Hepper, F.N., (1989) Pharaoh`s Flowers 'The Botanical Treasures of Tutankhamun', London, p. 59.

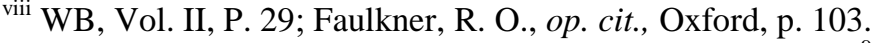
و وليم نظير، (1970) الثروة النباتية عند قدماء المصريين، القاهرة، ص 198 ـ

Chadefaud, C., Firmin, G., Villemonteix, J., (1990) Agriculture, Plantes Utiles, Alimentation, Cuisine chez les Neolithiques, les Egyptiens et Grecs anciens, in; Ecologie and Biogeographie, Paris, p.5 (11).

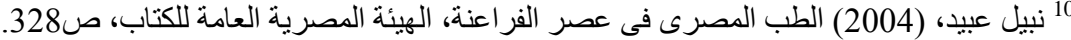

${ }^{11}$ Springuel, I., op.cit., p. 112, Tackholm, V., (1956) Students`Flora of Egypt, Cairo, p. 488; Darby, W. J., Ghalioungui, P., Grivetti, L., (1977) Food, the Gift of Osiris, London \& New York \& San Francisco, , p. 730; Kappel, S., Leoben, C., (2011) Garten im Alten Agypten und in Nubien, Rehden/ Westf, p. 46. ${ }^{12}$ Darby, W. J., Ghalioungui, P., Grivetti, L., op. cit., p. 731. ${ }^{13}$ Darby, W. J., Ghalioungui, P., Grivetti, L., ibid, p. 731.

${ }^{14}$ Barakat, H., Abd-el-aziz, I., (2010) Guide to Plants of Ancient Egypt, Egypt, p. 46.

${ }^{15}$ Darby, W. J., Ghalioungui, P., Grivetti, L., op. cit., p. 731

${ }_{16}$ Tackholm, V., op. cit., p. 488.

${ }^{17}$ Helck, W., Otto, E., ( 1977) Lexicon der Agyptologia, band ii, "Otto Harrassowitz. Wiesbaden", p. 267; Springuel, I., op. cit., p. 112; Marwan, N. Z., (1989) Egyptian Agricultural Life in the New Kingdom, Unpuplished Master,Helwan University, p. 198.

${ }^{18}$ Marwan, N. Z., op. cit., p. 198.

${ }^{18}$ Strouhel, R., (1992) Life of the ancient Egyptians, Cairo, p.129.

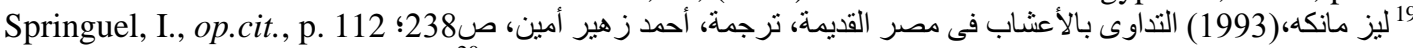

${ }^{20}$ Muschler, R., (1912) A Manual Flora of Egypt, Berlin, p. 188,189.

${ }^{21}$ Muschler, R., ibid, P. 189.

${ }^{22}$ Barakat, H., Abd-el-aziz, I., op. cit., p. 46.

${ }^{23}$ Allen, J.P., Redford, D. B., (2000) The Oxford Encyclopedia of Ancient Egypt, Vol. I, Cairo, p, 537-8; Darby, W. J., Ghalioungui, P., Grivetti, L., op. cit., London \& New York \& San Francisco, p. 731; Loret, V., (1892) La Flora Pharaoniqued après les documents hieroglyphiques et les specimens decouvertsdans les tombes, Paris, p. 34.

${ }^{24}$ Allen, J.P., Redford, D. B., op. cit., Vol. I, p. 280-1.

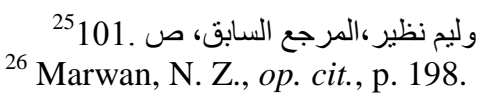

${ }^{27}$ Zahran, M. A., Willis, A. J., (2009) Plant and Vegetation, the Vegetation of Egypt, 2nd edition, springer, p. 102.

${ }^{28}$ Zahran, M. A., Willis, A. J., ibid, p. 104.

${ }^{x x x}$ Zahran, M. A., Willis, A. J., ibid, p. 105.

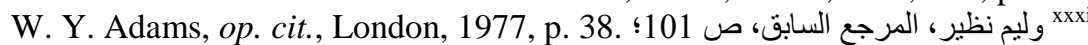

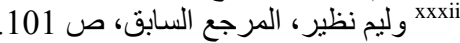

${ }^{33}$ Adams, W. Y., (1977) Nubia, Corridor to Africa, London, p. 275-6.

${ }^{34}$ Adams, W. Y., ibid, p. 38.

${ }^{\mathrm{xxxv}}$ Adams, W. Y., ibid, p. 38. 
${ }^{36}$ Darby, W. J., Ghalioungui, P., Grivetti, L., op. cit., London \& New York \&San Francisco, p. 730; Loret, V., op. cit.,pp. 33-4

${ }^{37}$ Springuel, I., op. cit., Cairo \& New york, p. 111, Darby, W. J., Ghalioungui, P., Grivetti, L., op. cit., London\& New York \& San Francisco, p. 730

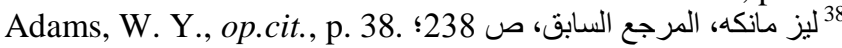
39 I. Springuel, op.cit., p. 111.

${ }^{40}$ Darby, W. J., Ghalioungui, P., Grivetti, L., op.cit., p. 731. ${ }^{41}$ Adams, W. Y., op.cit., p. 38. ${ }^{42}$ Marwan, N. Z., op.cit., p. 198 xliii Marwan, N. Z., ibid, p. 198. ${ }^{\text {xliv }}$ Wilkinson, A., (1998) The Garden in Ancient Egypt, The Rubicon Press, p. 8; Marwan, N. Z., op. cit., He p. 198. ${ }^{45}$ Marwan, N. Z., op. cit., p. 198.

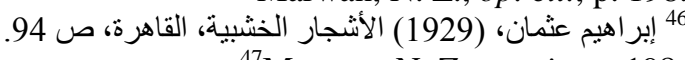

${ }^{47}$ Marwan, N. Z., op.cit., p. 198 .

${ }^{48}$ Wilson, H., (1999) People of the pharaohs 'from peasant to courtier', Brockhampton Press, p. 8.

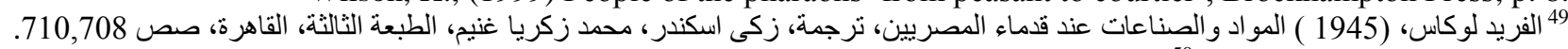
${ }^{50}$ Springuel, I., op.cit., p. 111

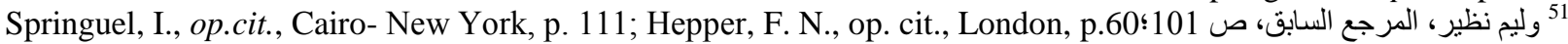

* Arm: It is a conventional unit of measurement to measure length. It has been used in many of measurements in different regions of the world in ancient history, middle Ages and in the early modern times. According to ancient Egyptian units of measurement, the royal arm was divided into seven palms of the hands off our fingers/digits, located between 52.3 and 52.9 centimeter; After: Arnold, D., (1991) Building in Egypt, Pharaonic stone masonry Oxford, New York Oxford University Press, p.251.

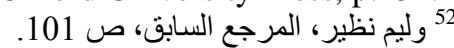

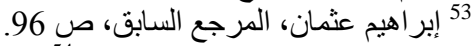

${ }^{54}$ Springuel, I., op.cit., p. 111.

${ }^{\text {lv }}$ Moursi, H., (1896) Die Heilpflanzen im Land der Pharaonen, Agyptisch- Nubische Volksmedizin, Kairo, p. 190.

${ }^{56}$ Hepper, F. N., op.cit., p. 59-60 ${ }^{57}$ Ibid, p. 60 .

${ }^{58}$ Allen, J.P., Redford, D. B., op. cit., Vol. I, p. 732. ${ }^{59}$ Darby, W. J., Ghalioungui, P., Grivetti, L., op.cit., p.732; N. Z. Marwan, op. cit., p. 202,203. ${ }^{60}$ Barakat, H., Abd-El-Aziz, I., op. cit., p. 46. ${ }^{61}$ Wilson, H., op.cit., p. 8. ${ }^{62}$ Springuel, I., The Desert Garden a practical guide, Cairo \& New York, p. 111 Barakat, H., Abd-El-Aziz, I., op. cit., p. 68

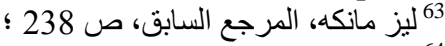

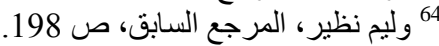

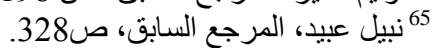

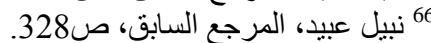

Darby, W. J., Ghalioungui, P., Grivetti, L., op.cit., p. 732.

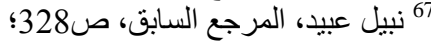

${ }^{68}$ Barakat, H., Abd-El-Aziz, I., op. cit., p. 46.

${ }^{69}$ Marwan, N. Z., op.cit., p. 199.

${ }^{70}$ Marwan, N. Z., op.cit., p. 200.

${ }^{71}$ Marwan, N. Z., op.cit., p. 200; Loret, V., op. cit., p. 34. ${ }^{72}$ Loret, V., op. cit., p. 34.

${ }^{73}$ H. Barakat, I. Abd-El-Aziz, op. cit., p. 46.

74 Wallert, I., (1962) Die Palmen im Alten Aegyptien, eine; MAS, Berlin, pp. 106-107.

${ }^{75}$ Darby, W. J., Ghalioungui, P., Grivetti, L., op. cit., p. 731.

${ }^{76}$ H. Barakat, I. Abd-elaziz,op. cit, p. 48.

${ }^{\text {lxxvii }}$ H. Barakat, I. Abd-elaziz,op. cit., p. 53; N. M. Arafa, op. cit., Caire, 1996, p. 49.

lxxviii Wallert, I., op. cit., p. 82.

${ }^{\text {lxxix }}$ Cornell, C. Van Siclen III, (1982) Two Theban Monuments from the reign of Amenhotep II, San Antonio, op. cit.,

p. 11.

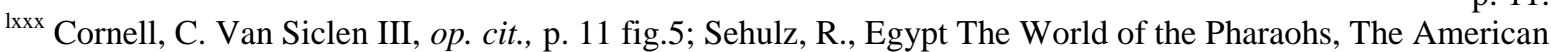
University in the Cairo Press, p. 386 fig. 96; Wallert, I., op. cit., p. 93. عز عزة صديق جاد الرب محمود، (2006) در اسة تحليلية للمسكن المصري في العمارة المصرية القديمة، رسالة ماجستير غير منشورة، جامعة حلوان، صص 138,140 شكل 90 ب؛

Marwan, N. Z., op. cit., Helwan University, 1989, p. 552 fig. 11. 
${ }^{82}$ Marwan, N. Z., op. cit., p. 553 fig. 12.

${ }^{83}$ Maspero, G., dcl oxon, op. cit., p. 182 fig. 171

${ }^{84}$ Catharine, H. R., Life along the Nile, Three Egyptian of Ancient Thebes, the Metropolitan Museum of Art, in: $M M A$, p. 51; Barakat H., Abd-Elaziz, I., op. cit., Egypt, 2010, p. 53.

${ }^{85}$ Catharine, H. R., op. cit, in: MMA, p. 51; Barakat, H., Abd-Elaziz, I., op. cit., Egypt, 2010, p. 53. lxxxvi Sehulz, R., op. cit., p.263 fig. 226.

lxxvii Tietze, C.,(2011) Agyptische Garten, eine; ARGMSK, vom 27. Mai biszum 6. November, p. 92.

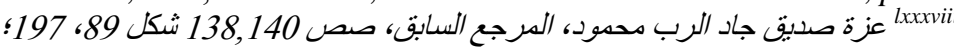

James, T. G. H., (1985) Egyptian painting and Drawing in the British museum, British museum press, pp. $29,52$. ${ }_{\text {lxxxix }}$ Manniche, L., op. cit., Cairo, 2006, p. 13.

${ }^{90}$ James, T. G. H., op. cit., British Museum Press, 1985.

${ }^{91}$ Maarten, H., Joost, K., Daniel. S., Others, (2010) Current research in Egyptology 2010, "Proceeding of the Eleventh Annual Symposium", Leiden University, p. 134, fig. 1.

${ }^{92}$ Maarten, H., Joost, K., Daniel. S., Others, op. cit, Leiden University, p. 134 fig. 1., p. 83; Woenig, F., (1971) Die Pflanzen Im Alten Aegypten, Amsterdam, p. 306-307.

${ }^{93}$ Maarten, H., Joost, K., Daniel. S., Others, op. cit., Leiden University 2010, p. 85.

${ }^{94}$ Davies, N. de G., (1930)The Tomb of Ken-Amun at Thebes, in; MMAEE, Vol. I, New York, P. 23.

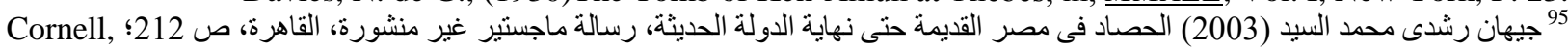
C., Van Siclen III, op. cit., San Antonio, 1982, p. 18, p. 19, fig. 12.

${ }^{96}$ III, op. cit., p. 19.

${ }^{97}$ Cornell, C., Van Siclen, ibid, p. 19.

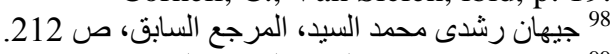

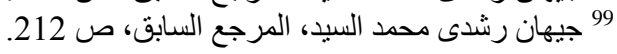

${ }^{100}$ Strudwick, N., (1996) The tombs of Amenhotep, Khnummose and Amenmose at Thebes, Vol. 1, "Griffith institute. Oxford, Ashmolean Museum", p. 37.

جيهان رشدي محمد السيد، المرجع السابق، صص :

Cornell, C.,Van Siclen III, op. cit., San Antonio, 1982, p. 20; Kozloff, A. P., Bryan, B. M., Berman, L. M., (1992)

Egypt`s Amenhotep III Dazzling sun and his world, Cleveland Museum of Art in Cooperation with Indiana University Press, p. 274.

cii Strudwick, N., op. cit., p. 38.

${ }^{103}$ Wallert I., op. cit., p. 80.

${ }^{104}$ Davies, N. de G., (1926) The Tomb of Huy, in; $\underline{T T S}$, London, , p. 23; Desroches, C., (1999) Le Secret des Temples de La Nubie, Noblecourt, p. 78.

${ }^{105}$ Wallert, I., op. cit., p. 80.

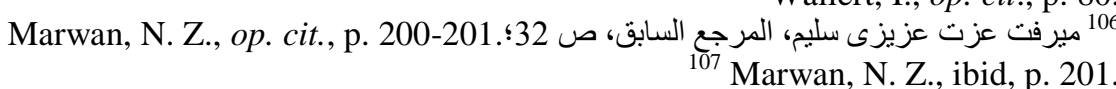

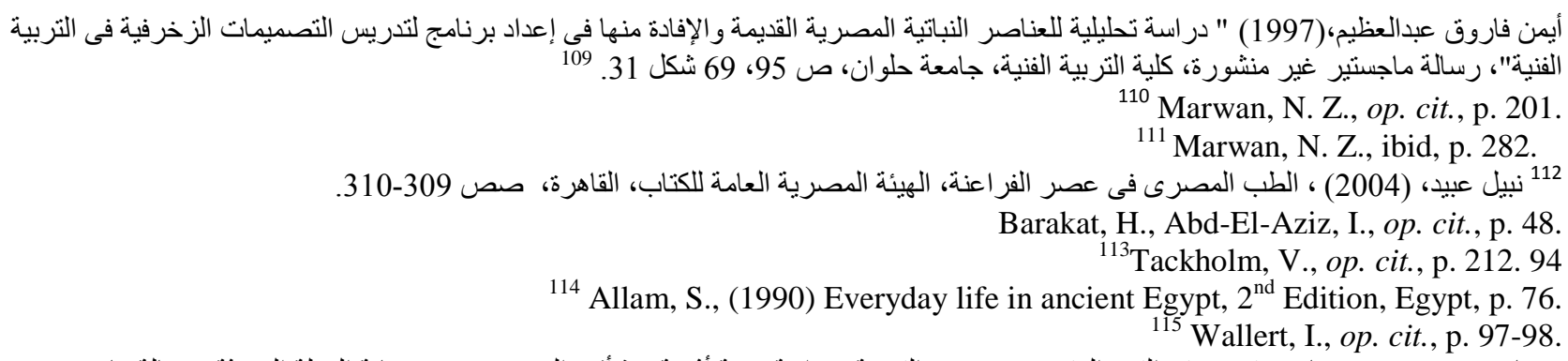

${ }^{114}$ Allam, S., (1990) Everyday life in ancient Egypt, $2^{\text {nd }}$ Edition, Egypt, p. 76.

${ }^{115}$ Wallert, I., op. cit., p. 97-98.

غادة محمد محمد بهنساوى (2006)، القرد المقس فى مصر القديمة، در اسة دينية أثرية منذ أقدم العصور وحتى نهاية الدولة الحديثة، رسالة ماجستير غير صنام

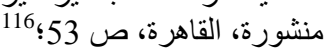

Vandier, J. D`Abbadie, (1937) Catalogue Des Ostraca Figures de Deir El Medineh, in; Ministere de L`Education

غادة محمد محمد بهنساوى، المرجع السابق، ص 53؛ 117 Nationale, vol. 1, Le Caire, P.195.

118 5ادة محمد محمد بهنساوى، المرجع السابق، ص Vandier, J. D` Abbadie, op. cit., Vol. 1, Le Caire, 1937, P.1

119 Arafa, N. M., (1996) Le Jardin chez L’Ancien Egyptien "au Nouvel Empire", le grade de Magistere, unpublished,

Caire, p. 178, Fig. 75.

${ }^{120}$ Vandier, J. D` Abbadie, op. cit., p. 3.

${ }^{121}$ Vandier, J. D` Abbadie, ibid, p. 2.

${ }^{122}$ Vandier, J. D` Abbadie, ibid, pp. 2-3. 
${ }^{123}$ Vandier, J. D` Abbadie, ibid, p. 3.

${ }^{124}$ Vandier, J. D` Abbadie, bid, pp. 2-3.

${ }^{125}$ Vandier, J. D' Abbadie, ibid, pp. 56-57.

${ }^{126}$ Vandier, J. D` Abbadie, ibid, p. 58.

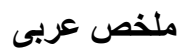

تعد أشجار النخيل من أهم الأشجار التى كانت ولازالت تزرع فهى من أهم الأشجار التى توفر الظل وتنقى الجو من الأتربة، و كل جزء من التاء

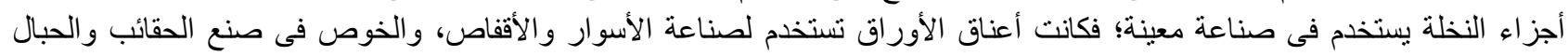

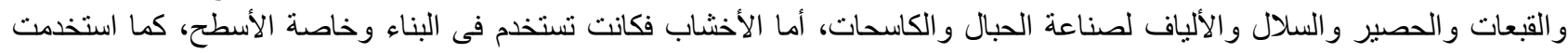

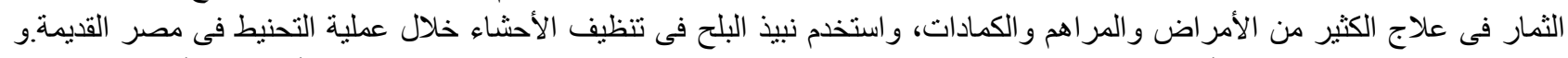

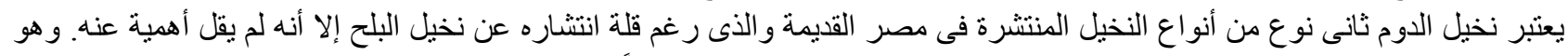

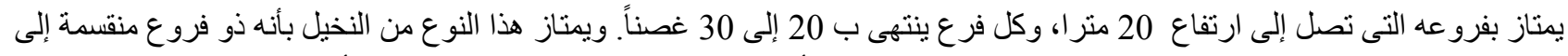

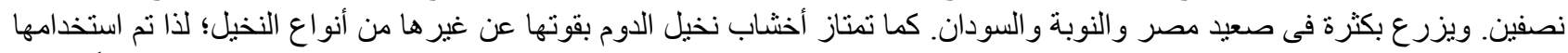

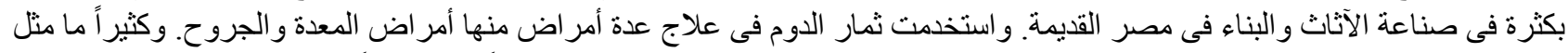
نخيل الدوم على جدران المقابر والمعابد فى مصر القديمة خاصة خلال عصر الدولة الحديثة منفرداً أو مصاحباً لنخيل البلح و العرجون. 